\title{
TRITIUM IN FLOW FROM SELECTED SPRINGS THAT DISCHARGE TO THE SNAKE RIVER, TWIN FALLS- HAGERMAN AREA, IDAHO, 1994-99
}

By Brian V. Twining

U.S. GEOLOGICAL SURVEY

Open-File Report 02-185

Prepared in cooperation with the

U.S. DEPARTMENT OF ENERGY

Idaho Falls, Idaho

May 2002 


\section{U.S. DEPARTMENT OF THE INTERIOR \\ GALE NORTON, Secretary}

U.S. GEOLOGICAL SURVEY

CHARLES G. GROAT, Director

Any use of trade, product, or firm names in this publication is for descriptive

purposes only and does not constitute endorsement by the U.S. Government.

For additional information write to:

U.S. Geological Survey

INEEL, MS 4148

P. O. Box 2230

Idaho Falls, ID 83403-2230
Copies of this report can be purchased from:

U.S. Geological Survey

Information Services

Box 25286, Denver Federal Center

Denver, CO 80225-0046 


\section{CONTENTS}

Abstract fow

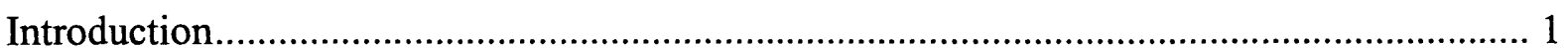

Geohydrologic setting ....................................................................................... 3

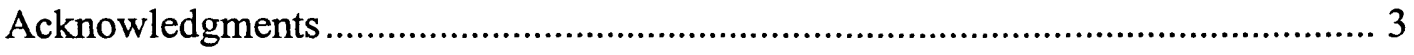

Methods and quality assurance

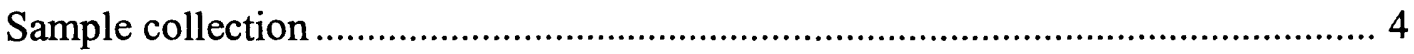

Reporting of data

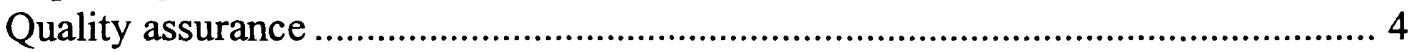

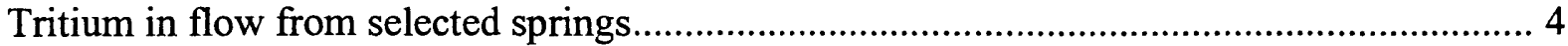

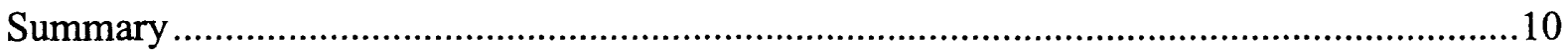

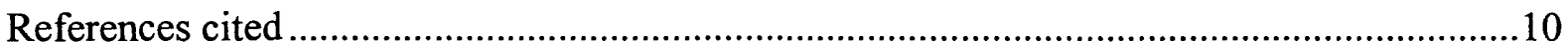

\section{FIGURES}

1. Map showing location of study area, between the Idaho National Engineering and Environmental Laboratory, and Hagerman, Idaho .................................................................. 2

2. Map showing locations of springs where water samples were collected for tritium analyses, Twin Falls-Hagerman area, Idaho, 1994-99................................................................. 5

3. Graph showing concentrations of tritium in selected Category I, II, and III springs, 1990-99

\section{TABLES}

1. Springs where water samples were collected for tritium analyses, Twin Falls-Hagerman area, Idaho, 1994-99

2. Physical and chemical characteristics of and tritium concentrations in water from selected springs in the Twin Falls-Hagerman area, Idaho, 1994-99...

\section{CONVERSION FACTORS AND OTHER ABBREVIATED UNITS}

$\begin{array}{rll}\text { Multiply } & \text { By } & \text { To Obtain } \\ \text { foot }(\mathrm{ft}) & 0.3048 & \text { meter } \\ \text { mile }(\mathrm{mi}) & 1.609 & \text { kilometer } \\ \text { square mile }\left(\mathrm{mi}^{2}\right) & 2.590 & \text { square kilometer } \\ \text { curie }(\mathrm{Ci}) & 3.7 \times 1010 & \text { becquerel } \\ \text { picocure per liter }(\mathrm{pCi} / \mathrm{L}) & 0.037 & \text { becquerel per liter } \\ \text { gallon }(\mathrm{gal}) & 3.785 & \text { liter }\end{array}$

Temperature can be converted from degrees Celsius $\left({ }^{\circ} \mathrm{C}\right)$ to degrees Fahrenheit $\left({ }^{\circ} \mathrm{F}\right)$ by the equation: ${ }^{\circ} \mathrm{F}=\left({ }^{\circ} \mathrm{C} \times 1.8\right)+32$. 


\title{
Tritium in Flow from Selected Springs that Discharge to the Snake River, Twin Falls- Hagerman Area, Idaho, 1994-99
}

\author{
By Brian V. Twining
}

\begin{abstract}
During 1994-99, the U.S. Geological Survey, in cooperation with the U.S. Department of Energy, collected samples for tritium analyses from 19 springs along the north side of the Snake River near Twin Falls and Hagerman, Idaho, to address public concern over migration of approximately $31,000 \mathrm{Ci}$ of tritium discharged in wastewater at the Idaho National Engineering and Environmental Laboratory (INEEL). Evaluating tritium for the Twin Falls-Hagerman area is part of a long-term project to monitor water quality of springs discharging from the Snake River Plain aquifer downgradient from the INEEL. Routine and two quality-assurance replicate samples have been collected annually since 1990 as part of the U.S. Geological Survey's quality-assurance program.
\end{abstract}

The springs were characterized on the basis of their locations and tritium concentrations:

Category I, II, and III. The differences in tritium concentrations in Category I, II, and III springs are a function of the ground-water flow regimes, land uses, and irrigation practices in and hydraulically upgradient from each category of springs. Tritium concentrations during the 1994-99 water years ranged from a low $6.5 \pm 0.6$ picocuries per liter (pCi/L) to a high of $65.0 \pm 4.5 \mathrm{pCi} / \mathrm{L}$. During 1999 , tritium concentrations in the 19 springs ranged from $6.5 \pm 0.6 \mathrm{pCi} / \mathrm{L}$ to $46.1 \pm 3.2 \mathrm{pCi} / \mathrm{L}$. Mean annual tritium concentrations measured from 1990 to 1999 in selected springs from each category show decreasing trends in tritium values, likely the result of natural isotope decay.

\section{INTRODUCTION}

Concern has been expressed that some of the approximately $31,000 \mathrm{Ci}$ of tritium discharged in wastewater to the Snake River Plain aquifer at the
Idaho National Engineering and Environmental Laboratory (INEEL) has migrated or will migrate to the Snake River in the Twin Falls-Hagerman area (fig. 1). The INEEL, located about $100 \mathrm{mi}$ northeast of Twin Falls and about 110 mi northeast of Hagerman, comprises $890 \mathrm{mi}^{2}$ of the northeastern part of the eastern Snake River Plain (ESRP) and overlies the ESRP aquifer. Injection wells at INEEL were used regularly until 1984 and infiltration ponds continue to be used to dispose of wastewater that could contain radioactive and chemical contaminants. Ground water downgradient from the INEEL is used for drinking, irrigation, and aquaculture.

An extensive monitoring network is maintained by the USGS to collect geohydrologic, hydraulic, geochemical, and radioisotope data at and downgradient from the INEEL. This continuing monitoring program provides information needed to inform the public to prevailing water-quality conditions in the aquifer system and to support the current and planned geohydrologic research that could help water-resource managers resolve issues that concern the migration and disposition of radioactive and chemical wastes.

Radioactive and chemical wastes have migrated as much as $13 \mathrm{mi}$ southwest of the disposal areas at the INEEL (Bartholomay and others, 2000). Tritium was detected intermittently at concentrations of $3,400 \pm 200 \mathrm{pCi} / \mathrm{L}$ or less in water from three wells along the southern boundary of the INEEL between 1983 and 1985 (Pittman and others, 1988). From April 1985 to October 1995, tritium concentrations in water from wells near the southern boundary of the INEEL were less than the laboratory minimum reporting level (Bartholomay and others, 1997); however, in 1998, because of lower laboratory detection limits used, tritium concentrations in water from one well at the boundary and one well south of the boundary exceeded the 


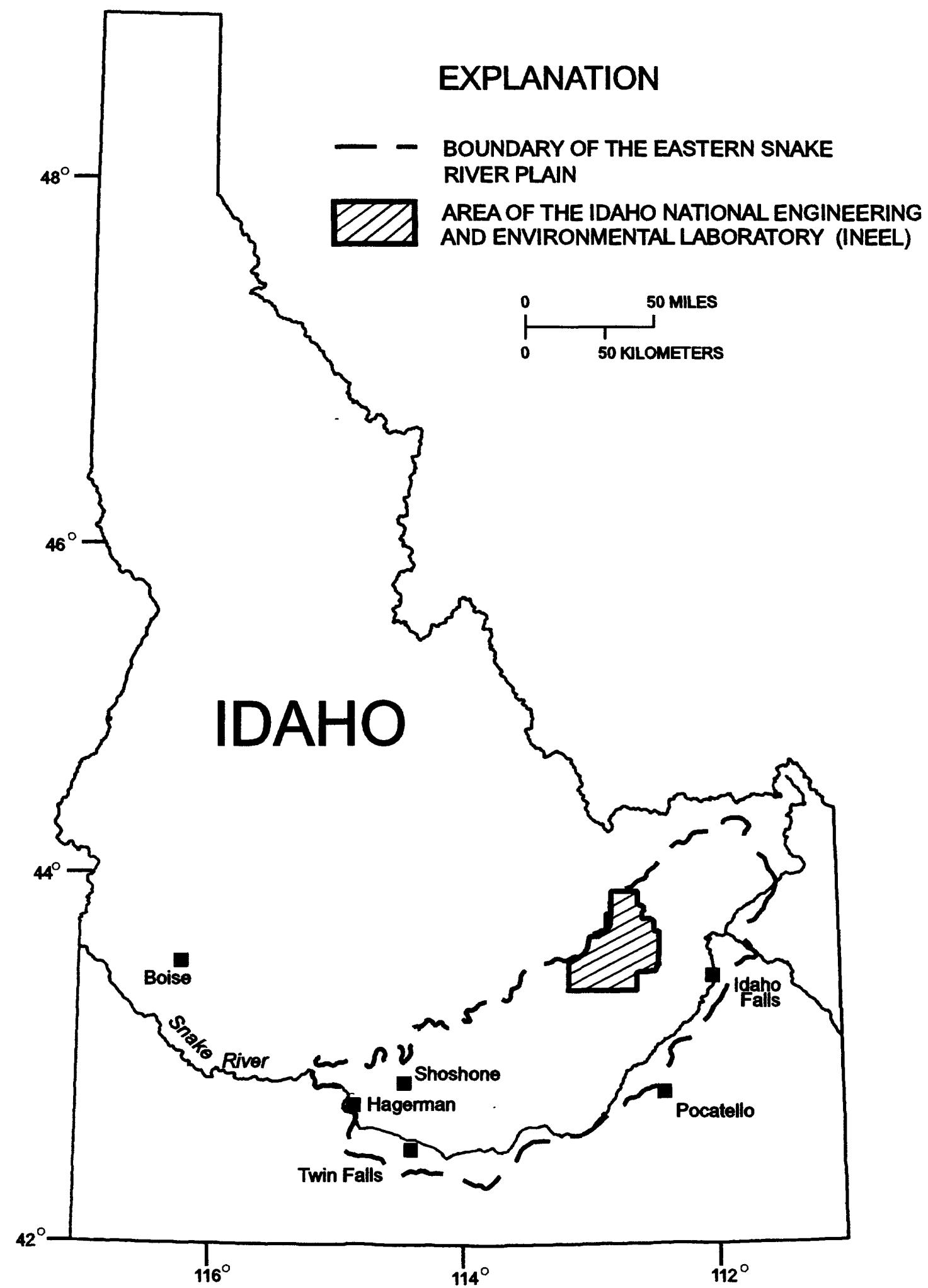

Figure 1. Location of the study area, between the Idaho National Engineering and Environmental Laboratory and Hagerman, Idaho. 
reporting level and were $310 \pm 60$ and $300 \pm 60 \mathrm{pCi} /$ $\mathrm{L}$, respectively (Bartholomay and others, 2000).

Tritium, a radioactive isotope of hydrogen, is a naturally occurring isotope with a 12.3-year halflife and is produced by reaction of cosmic rays with nitrogen in the upper atmosphere (Walker and others, 1989). It also is a radioactive waste product from nuclear power plant operations, fuel processing, and weapons production and testing. Before atmospheric testing of nuclear weapons in the 1950 's and 1960's, the average background tritium concentration in environmental waters from cosmic-ray production was less than $16 \mathrm{pCi} / \mathrm{L}$ (National Council on Radiation Protection and Measurements, 1979). Atmospheric weapons tests markedly increased tritium concentrations in precipitation and surface water. In 1963, the mean concentration of tritium in surface water of the United States was about 3,500 pCi/L. By 1990, however, the mean concentration in surface water was about $65 \mathrm{pCi} / \mathrm{L}$ (R.L. Michel, USGS, oral commun., 1992). For comparison, the maximum contaminant level for tritium in public drinkingwater supplies is $20,000 \mathrm{pCi} / \mathrm{L}$ (U.S. Environmental Protection Agency, 1983, p. 236).

This study is part of a long-term project, established by the U.S.Geological Survey (USGS) in cooperation with the U.S. Department of Energy, to monitor tritium concentrations in spring discharge to the Snake River in the Twin FallsHagerman area. Since 1989, water samples have been collected from 19 springs along the north side of the Snake River in this area. This report documents tritium concentrations in samples from spring flow collected during 1994-99 from the Twin Falls-Hagerman area. Additionally, tritium data from 1990-93 will be evaluated within this report taken from Mann and Low (1994).

\section{Geohydrologic Setting}

The ESRP aquifer is the major aquifer in southeastern Idaho and includes an area of approximately $15,600 \mathrm{mi}^{2}$ and is about $200 \mathrm{mi}$ long and 50 to $70 \mathrm{mi}$ wide. The aquifer extends from Dubois, Idaho, southwest to the main discharge area near Twin Falls, Idaho (fig. 1). The general direction of ground-water movement within the ESRP is from the northeast to southwest. Concentrations of chlorine- 36 indicate that the average ground-water flow velocity is at least $10 \mathrm{ft} /$ day for the Snake River Plain aquifer (Cecil and others, 2000). Sources of recharge to the aquifer include infiltration from irrigation, rainfall, and valley underflow.

The ESRP is underlain by a layered sequence of basaltic lava flows and cinder beds intercalated with alluvium and lakebed sedimentary deposits. Individual lava flows generally range from 10 to $50 \mathrm{ft}$ in thickness, and average 20 to $25 \mathrm{ft}$ in thickness (Mundorff and others, 1964, p. 143). Locally, rhyolitic lava flows and tuffs are exposed at the land surface or occur at depth. The sedimentary deposits consist mainly of lenticular beds of sand, silt, and clay with lesser amounts of gravel. The basaltic lava flows and intercalated sedimentary deposits combine to form the Snake River Plain aquifer, which is the main source of ground water to the ESRP. Irrigation is the primary use of ground water in this region (Mann and Low, 1994).

\section{Acknowledgments}

The author gratefully acknowledges the following employees of the USGS who collected the water samples and made field measurements of $\mathrm{pH}$, specific conductance, and temperature: Betty J. Tucker, Michael .J. Greene, and Roy C. Bartholomay. The author would also like to express appreciation to land owners and spring owners for allowing the USGS to collect samples. Special gratitude is owed to USGS hydrologists Roy C. Bartholomay, LeRoy L. Knobel, and Deborah Parliman for their reviews and constructive comments of this report.

\section{METHODS AND QUALITY ASSURANCE}

Methods used to collect and analyze water samples for tritium generally followed guidelines established by the USGS (Wood, 1976; Thatcher and others, 1977; and Wilde and others, 1998). Sampling methods used in the field and the method used to report tritium concentrations are outlined in the following sections.

Samples collected during 1994-99 were analyzed using an electrolytic-enrichment, gas-counting method with an analytical method detection limit of $0.3 \mathrm{pCi} / \mathrm{L}$ and a 360 - to 1,200 -minute counting period. This method primarily is limited 
to the analyses of samples that contain concentrations of tritium between 0.2 and $100 \mathrm{pCi} / \mathrm{L}$ (Pritt and Jones, 1989, p. 5-19).

\section{Sample Collection}

Water samples for tritium analyses were collected in 1-L polyethylene bottles and were not treated before or after being bottled in the field. Samples were collected as close as reasonably possible to the spring orifices. Some springs had multiple orifices or the flow was diverted for use by fish hatcheries. Where possible, the samples were collected upstream from diversions. The 1-L polyethylene bottle was lowered by hand in the area of the orifice or in the channel downstream from the orifice(s). Where flow was channeled, care was taken to sample flowing discharge; water in eddies and ponded areas was avoided. The bottle was rinsed at least three times with spring water before sample collection. After collection, the bottle immediately was capped, and the exterior was dried; laboratory film was placed around the cap, and a label that included identification information for the sample was attached to the bottle. The samples were documented and placed in a secured vehicle or in the USGS INEEL Project Office until they were shipped to the USGS National Water Quality Laboratory (NWQL).

Physical conditions, temperature, $\mathrm{pH}$, and specific conductance at the springs during sample collection were measured and recorded in a field logbook. A chain-of-custody record was used to track the samples from the time of collection until delivery to the analyzing laboratory. These records are available for inspection at the USGS INEEL Project Office.

\section{Reporting of Data}

For each tritium concentration, an associated analytical uncertainty, $2 \mathrm{~s}$, was calculated such that there was a 95-percent probability that the true tritium concentration in a sample was in the range of the reported concentration plus or minus the analytical uncertainty. For example, given an analytical result of $11.0 \pm 1.0 \mathrm{pCi} / \mathrm{L}$, there is a 95 percent probability that the true concentration is in the range of 10.0 to $12.0 \mathrm{pCi} / \mathrm{L}$.

\section{Quality Assurance}

Detailed descriptions of internal quality control (QC) and overall quality-assurance (QA) practices used by the NWQL are provided in reports by Friedman and Erdmann (1982), Jones (1987), and Pritt and Raese (1995). Water samples analyzed by the NWQL were collected in accordance with a quality-assurance plan for quality-of-water activities conducted by personnel at the INEEL Project Office. The plan was finalized in June 1989, revised in March 1992 and in 1996 (Mann, 1996), and is available for inspection at the USGS INEEL Project Office.

Approximately 10 percent of the water samples were quality-assurance replicate samples, two of which were collected each year of sampling. Replicate sample concentrations were similar to corresponding spring data at each site. Differences between replicate samples were small enough to suggest that sampling/analytical variations do not affect the spring classifications and trends presented in this report.

\section{TRITIUM IN FLOW FROM SELECTED SPRINGS}

During 1994-99, water samples were collected from 19 springs (fig. 2). For ease of discussion, the springs were categorized on the basis of their locations and tritium concentrations as described by Mann and Low (1994) (fig. 2 and table 1). Category I springs, the springs farthest upstream, include Devils Washbowl, Devils Corral (upper), Unnamed Spring No. 2 above Shoshone Falls, Blue Lakes, Warm Creek, and Crystal Springs. Tritium concentrations in the flow from these springs were markedly greater than concentrations in flow from downstream springs. Category II springs include Clear Lakes, Briggs Creek, Banbury, Unnamed Spring between Blind and Banbury near Buhl, Blind Canyon, Box Canyon, Blue Heart, Sand, Thousand, Bickel, Riley Creek, and Billingsley Creek Springs. Category III consists of Birch Creek Spring, at which the tritium concentration was less than the concentration in Category I springs, but greater than the concentrations in Category II springs. Physical and chemical characteristics of and tritium concentrations in water samples for the 19 springs are presented in table 2 . 

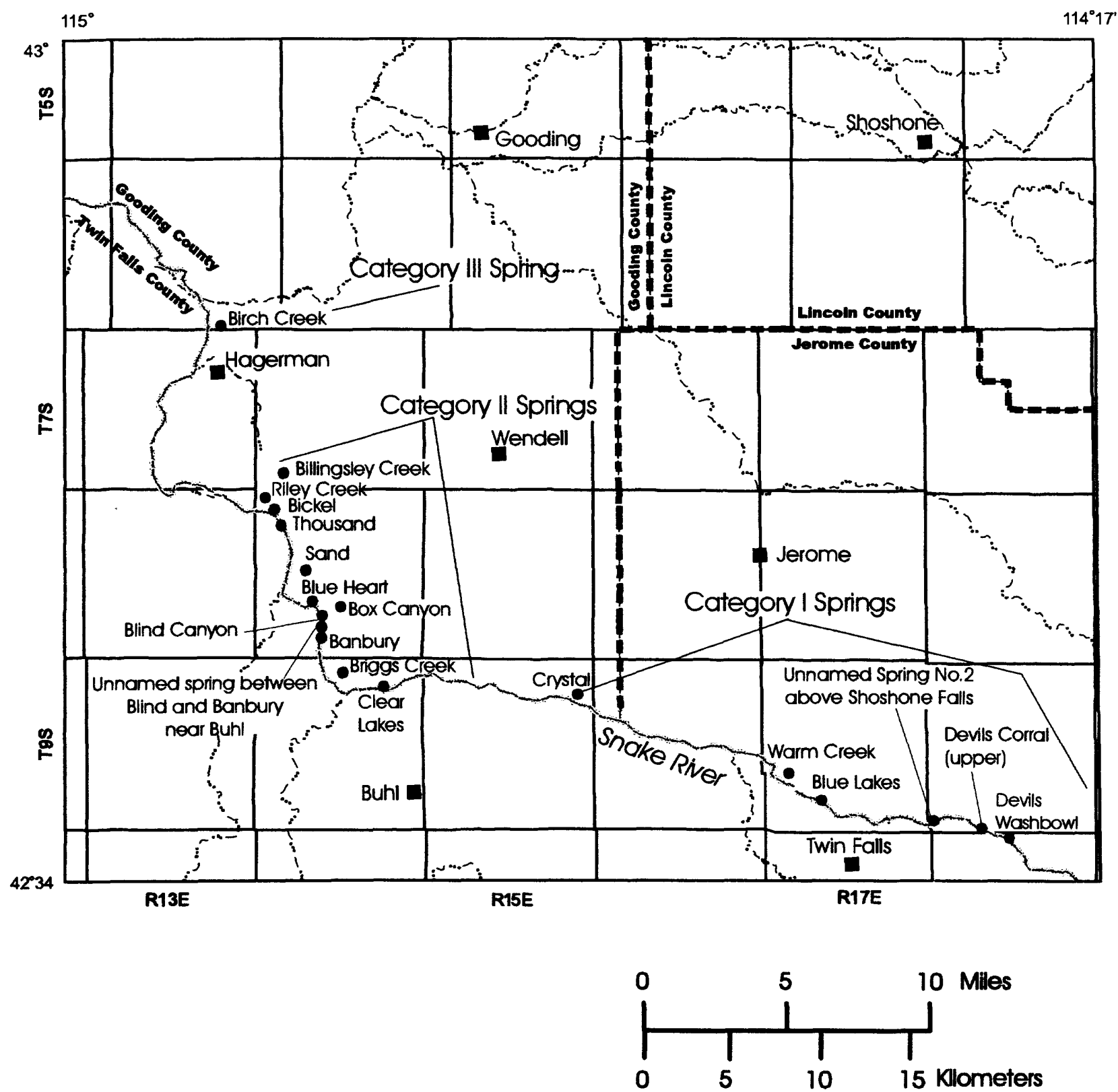

Figure 2. Locations of springs where water samples were collected for tritium analyses, Twin FallsHagerman area, Idaho, 1994-99. 
Table 1. Springs where water samples were collected for tritium analyses, Twin Falls-Hagerman area, Idaho, 1994-99

[Springs are listed in downstream order; see figure 2 for locations]

\begin{tabular}{lcl}
\hline Devils Washbowl & $\begin{array}{c}\text { Category I Springs } \\
\text { Unnamed Spring No.2 } \\
\text { above Shoshone Falls } \\
\text { Blue Lakes }\end{array}$ & Warm Creek \\
Devils Corral (upper) & Category II Springs & Crystal \\
Clear Lakes & Blind Canyon & Thousand \\
Briggs Creek & Box Canyon & Bickel \\
Banbury & Blue Heart & Riley Creek \\
Unnamed spring between & Sand & Billingsley Creek \\
Blind and Banbury & Category III Spring & \\
Birch Creek & & \\
\hline
\end{tabular}

Table 2. Physical and chemical characteristics of and tritium concentrations in water from selected springs in the Twin Falls-Hagerman area, Idaho, 1994-99

[See figure 2 for locations of springs and table 1 for their downstream order. Tritium concentrations and analytical uncertainties, in picocuries per liter,determined by U.S. Geological Survey's National Water Quality Laboratory, Arvada, Colo.; analytical uncertainties reported as $2 \mathrm{~s}$. Time, in military units; temperature, in degrees Celsius; ph, negative base-10 logarithm of hydrogen ion activity in moles per liter; specific conductance, in microsiemens per centimeter at 25 degrees Celsius. Remarks: Replicate indicates a second sample was submitted for analysis. Abbreviations: nr, near; NA, temperature was not measured]

\begin{tabular}{|c|c|c|c|c|c|c|c|}
\hline Spring(s) name & $\begin{array}{c}\text { Date } \\
\text { sampled }\end{array}$ & Time & $\begin{array}{l}\text { Temper- } \\
\text { ature }\end{array}$ & $\mathrm{pH}$ & $\begin{array}{c}\text { Specific } \\
\text { conductance }\end{array}$ & $\begin{array}{c}\text { Tritium } \\
\text { concentration } \\
\text { and analytical } \\
\text { uncertainty }\end{array}$ & Remarks \\
\hline \multicolumn{8}{|c|}{ Category I Springs } \\
\hline Blue Lakes & $3 / 09 / 94$ & 1030 & 15.8 & 8.0 & 632 & $58.0 \pm 3.8$ & \\
\hline \multirow[t]{5}{*}{ Outlet nr Twin Falls } & $3 / 28 / 95$ & 0945 & 15.4 & 7.8 & 629 & $47.0 \pm 3.2$ & \\
\hline & $3 / 13 / 96$ & 0845 & 15.8 & 7.6 & 621 & $48.0 \pm 3.2$ & \\
\hline & $3 / 17 / 97$ & 1455 & 15.6 & 8.2 & 623 & $45.4 \pm 3.2$ & \\
\hline & $3 / 09 / 98$ & 1520 & 15.6 & 7.9 & 620 & $44.8 \pm 3.2$ & \\
\hline & $3 / 15 / 99$ & 1515 & 15.2 & 7.9 & 615 & $38.4 \pm 2.6$ & \\
\hline Crystal Springs & $3 / 09 / 94$ & 1215 & 14.7 & 8.2 & 698 & $53.0 \pm 3.8$ & \\
\hline \multirow[t]{5}{*}{ nr Buhl } & $3 / 28 / 95$ & 1130 & 14.3 & 8.2 & 696 & $49.0 \pm 2.6$ & \\
\hline & $3 / 12 / 96$ & 1215 & 14.7 & 8.3 & 695 & $47.0 \pm 3.2$ & \\
\hline & $3 / 17 / 97$ & 1325 & 14.5 & 8.3 & 702 & $46.4 \pm 3.2$ & \\
\hline & $3 / 09 / 98$ & 1420 & 14.5 & 8.2 & 696 & $44.8 \pm 3.2$ & \\
\hline & $3 / 15 / 99$ & 1725 & 14.1 & 8.0 & 687 & $39.7 \pm 2.6$ & \\
\hline Devils Corral & $3 / 07 / 94$ & 1045 & 14.6 & 7.9 & 640 & $61.0 \pm 3.8$ & \\
\hline (Upper Outlet) & $3 / 27 / 95$ & 1220 & 15.1 & 8.5 & 633 & $55.0 \pm 2.6$ & \\
\hline \multirow[t]{4}{*}{ nr Kimberly } & $3 / 12 / 96$ & 1030 & 15.0 & 7.8 & 603 & $52.0 \pm 3.2$ & \\
\hline & $3 / 19 / 97$ & 0900 & 15.0 & 8.0 & 655 & $46.4 \pm 3.2$ & \\
\hline & $3 / 11 / 98$ & 0845 & 14.6 & 8.0 & 636 & $50.2 \pm 3.2$ & \\
\hline & $3 / 15 / 99$ & 0935 & 15.1 & 8.1 & 629 & $44.5 \pm 3.2$ & \\
\hline
\end{tabular}


Table 2. Physical and chemical characteristics of and tritium concentrations in water from selected springs in the Twin Falls-Hagerman area, Idaho, 1994-99-Continued

\begin{tabular}{|c|c|c|c|c|c|c|c|}
\hline Spring(s) name & $\begin{array}{c}\text { Date } \\
\text { sampled }\end{array}$ & Time & $\begin{array}{l}\text { Temper- } \\
\text { ature }\end{array}$ & $\mathrm{pH}$ & $\begin{array}{c}\text { Specific } \\
\text { conductance }\end{array}$ & $\begin{array}{c}\text { Tritium } \\
\text { concentration } \\
\text { and analytical } \\
\text { uncertainty }\end{array}$ & Remarks \\
\hline \multicolumn{8}{|c|}{ Category I Springs - continued } \\
\hline Devils Washbowl & $3 / 07 / 94$ & 0820 & 12.7 & 8.1 & 664 & $65.0 \pm 4.5$ & \\
\hline \multirow[t]{6}{*}{ Spring nr Kimberly } & $3 / 27 / 95$ & 0910 & 12.6 & 8.5 & 652 & $55.0 \pm 3.8$ & \\
\hline & $3 / 12 / 96$ & 1245 & 14.5 & 8.4 & 614 & $57.0 \pm 3.8$ & \\
\hline & $3 / 19 / 97$ & 1150 & 15.1 & 8.7 & 645 & $53.4 \pm 3.8$ & \\
\hline & $3 / 11 / 98$ & 1035 & 13.6 & 8.4 & 649 & $51.8 \pm 3.2$ & \\
\hline & $3 / 15 / 99$ & 1145 & 13.6 & 8.2 & 644 & $46.1 \pm 3.2$ & \\
\hline & & & & & & $44.8 \pm 3.2$ & Replicate \\
\hline Unnamed Spring & $3 / 12 / 96$ & 0800 & 12.8 & 8.1 & 604 & $50.0 \pm 3.2$ & \\
\hline No 2 above & $3 / 18 / 97$ & 1530 & 16.2 & 8.3 & 615 & $47.4 \pm 3.2$ & \\
\hline \multirow[t]{2}{*}{ Shoshone Falls } & $3 / 10 / 98$ & 1440 & 14.0 & 8.3 & 613 & $44.8 \pm 3.2$ & \\
\hline & $3 / 15 / 99$ & 1410 & 13.4 & 8.0 & 613 & $39.4 \pm 2.6$ & \\
\hline Warm Creek & $3 / 09 / 94$ & 0930 & 15.2 & 7.8 & 648 & $56.0 \pm 3.8$ & \multirow{7}{*}{ Replicate } \\
\hline at Perrine Ranch & $3 / 28 / 95$ & 0855 & 15.3 & 7.9 & 646 & $54.0 \pm 3.8$ & \\
\hline \multirow[t]{5}{*}{ nr Twin Falls } & $3 / 13 / 96$ & 0945 & 15.7 & 7.9 & 632 & $46.0 \pm 3.2$ & \\
\hline & $3 / 17 / 97$ & 1550 & 15.4 & 8.0 & 631 & $44.5 \pm 3.2$ & \\
\hline & & & & & & $46.4 \pm 3.2$ & \\
\hline & $3 / 09 / 98$ & 1605 & 15.4 & 7.8 & 627 & $44.2 \pm 3.2$ & \\
\hline & $3 / 15 / 99$ & 1600 & 15.1 & 7.7 & 624 & $40.3 \pm 2.6$ & \\
\hline \multicolumn{8}{|c|}{ Category II Springs } \\
\hline Banbury & $3 / 09 / 94$ & 1045 & 12.7 & 9.1 & 434 & $11.0 \pm 1.0$ & \multirow{7}{*}{ Replicate } \\
\hline \multirow{6}{*}{ Spring nr Buhl } & $3 / 28 / 95$ & 1315 & 13.9 & 8.8 & 422 & $9.1 \pm 0.8$ & \\
\hline & $3 / 11 / 96$ & 1030 & 14.0 & 7.9 & 436 & $8.7 \pm 0.6$ & \\
\hline & $3 / 18 / 97$ & 1010 & 13.3 & 8.5 & 447 & $9.2 \pm 0.6$ & \\
\hline & $3 / 10 / 98$ & 0915 & 12.5 & 8.4 & 437 & $8.1 \pm 0.6$ & \\
\hline & & & & & & $7.9 \pm 0.6$ & \\
\hline & $3 / 16 / 99$ & 1020 & 12.4 & 8.5 & 428 & $7.1 \pm 0.6$ & \\
\hline \multirow{6}{*}{$\begin{array}{l}\text { Bickel Spring } \\
\text { nr Hagerman }\end{array}$} & $3 / 07 / 94$ & 1334 & 15.7 & 8.4 & 329 & $9.7 \pm 0.8$ & \\
\hline & $3 / 27 / 95$ & 1300 & 15.4 & 8.3 & 330 & $8.7 \pm 0.6$ & \\
\hline & $3 / 11 / 96$ & 1215 & 15.7 & 8.3 & 327 & $8.1 \pm 0.6$ & \\
\hline & $3 / 17 / 97$ & 1010 & 15.0 & 8.3 & 337 & $7.7 \pm 0.6$ & \\
\hline & $3 / 09 / 98$ & 1020 & NA & 8.2 & 329 & $7.9 \pm 0.6$ & \\
\hline & $3 / 16 / 99$ & 1448 & 14.8 & 8.4 & 329 & $6.5 \pm 0.6$ & \\
\hline \multirow{7}{*}{$\begin{array}{l}\text { Billingsley Creek } \\
\text { nr Hagerman }\end{array}$} & $3 / 07 / 94$ & 1200 & 13.1 & 8.2 & 372 & $13.0 \pm 0.8$ & \multirow{7}{*}{ Replicate } \\
\hline & $3 / 27 / 95$ & 1124 & 13.4 & 8.2 & 388 & $12.0 \pm 0.9$ & \\
\hline & $3 / 11 / 96$ & 1010 & 13.9 & 8.1 & 378 & $10.0 \pm 0.7$ & \\
\hline & $3 / 17 / 97$ & 0905 & 14.8 & 7.8 & 357 & $8.6 \pm 0.6$ & \\
\hline & & & & & & $8.8 \pm 0.8$ & \\
\hline & $3 / 09 / 98$ & 0920 & 14.0 & 7.8 & 353 & $9.3 \pm 0.8$ & \\
\hline & $3 / 16 / 99$ & 1400 & 14.6 & 8.3 & 347 & $6.9 \pm 0.6$ & \\
\hline
\end{tabular}


Table 2. Physical and chemical characteristics of and tritium concentrations in water from selected springs in the Twin Falls-Hagerman area, Idaho, 1994-99-Continued

\begin{tabular}{|c|c|c|c|c|c|c|c|}
\hline Spring(s) name & $\begin{array}{c}\text { Date } \\
\text { sampled }\end{array}$ & Time & $\begin{array}{l}\text { Temper- } \\
\text { ature }\end{array}$ & $\mathrm{pH}$ & $\begin{array}{l}\text { Specific } \\
\text { conductance }\end{array}$ & $\begin{array}{c}\text { Tritium } \\
\text { concentration } \\
\text { and analytical } \\
\text { uncertainty }\end{array}$ & Remarks \\
\hline \multicolumn{8}{|c|}{ Category II Springs - continued } \\
\hline Blind Canyon & $3 / 09 / 94$ & 0845 & 11.5 & 8.6 & 452 & $9.2 \pm 0.8$ & \multirow{7}{*}{ Replicate } \\
\hline Spring nr & $3 / 28 / 95$ & 1430 & 13.7 & 8.5 & 457 & $9.6 \pm 0.9$ & \\
\hline \multirow[t]{5}{*}{ Buhl } & $3 / 11 / 96$ & 1230 & 14.5 & 8.4 & 463 & $9.4 \pm 0.6$ & \\
\hline & & & & & & $9.8 \pm 0.7$ & \\
\hline & $3 / 18 / 97$ & 1130 & 14.0 & 8.4 & 451 & $8.8 \pm 0.6$ & \\
\hline & $3 / 10 / 98$ & 1105 & 12.4 & 8.6 & 537 & $9.7 \pm 0.6$ & \\
\hline & $3 / 16 / 99$ & 1130 & 12.1 & 8.7 & 537 & $8.6 \pm 0.7$ & \\
\hline \multirow[t]{6}{*}{ Blue Heart Spring } & $3 / 09 / 94$ & 1200 & 14.4 & 8.5 & 401 & $9.2 \pm 0.8$ & \\
\hline & $3 / 28 / 95$ & 1505 & 14.1 & 8.0 & 393 & $8.1 \pm 0.8$ & \\
\hline & $3 / 11 / 96$ & 1315 & 15.0 & 7.6 & 397 & $9.5 \pm 0.7$ & \\
\hline & $3 / 18 / 97$ & 0950 & 14.4 & 7.9 & 407 & $7.6 \pm 0.6$ & \\
\hline & $3 / 10 / 98$ & 0845 & 14.4 & 7.7 & 409 & $7.2 \pm 0.6$ & \\
\hline & $3 / 16 / 99$ & 0955 & 14.1 & 8.2 & 398 & $6.9 \pm 0.6$ & \\
\hline \multirow{7}{*}{$\begin{array}{l}\text { Box Canyon } \\
\text { Spring nr Wendall }\end{array}$} & $3 / 08 / 94$ & 1030 & 14.3 & 7.6 & 404 & $11.0 \pm 0.7$ & \multirow{7}{*}{ Replicate } \\
\hline & & & & & & $10.0 \pm 0.7$ & \\
\hline & $3 / 29 / 95$ & 0900 & 14.0 & 8.3 & 426 & $10.0 \pm 0.8$ & \\
\hline & $3 / 12 / 96$ & 1100 & 14.6 & 8.2 & 424 & $9.5 \pm 0.7$ & \\
\hline & $3 / 18 / 97$ & 1355 & 15.0 & 8.2 & 431 & $9.3 \pm 0.6$ & \\
\hline & $3 / 09 / 98$ & 1150 & 14.3 & 8.1 & 416 & $8.5 \pm 0.6$ & \\
\hline & $3 / 16 / 99$ & 1615 & 13.8 & 8.1 & 417 & $8.1 \pm 0.6$ & \\
\hline \multirow{7}{*}{$\begin{array}{l}\text { Briggs Creek } \\
\text { Spring nr Buhl }\end{array}$} & $3 / 07 / 94$ & 1456 & 14.3 & 7.8 & 487 & $13.0 \pm 0.9$ & \multirow{7}{*}{ Replicate } \\
\hline & & & & & & $12.0 \pm 0.8$ & \\
\hline & $3 / 28 / 95$ & 1330 & 14.1 & 7.9 & 496 & $12.0 \pm 0.8$ & \\
\hline & $3 / 12 / 96$ & 0900 & 14.3 & 7.9 & 495 & $12.0 \pm 0.8$ & \\
\hline & $3 / 17 / 97$ & 1155 & 14.1 & 7.9 & 512 & $11.5 \pm 0.8$ & \\
\hline & $3 / 09 / 98$ & 1245 & 14.1 & 7.7 & 489 & $10.1 \pm 0.6$ & \\
\hline & $3 / 16 / 99$ & 1740 & 13.7 & 7.8 & 487 & $9.0 \pm 0.7$ & \\
\hline Clear Lakes & $3 / 08 / 94$ & 1445 & 14.0 & 7.3 & 475 & $13.0 \pm 1.0$ & \\
\hline \multirow[t]{5}{*}{ Outlet nr Buhl } & $3 / 29 / 95$ & 1125 & 13.7 & 8.0 & 454 & $10.0 \pm 0.8$ & \\
\hline & $3 / 13 / 96$ & 0830 & 13.9 & 7.7 & 461 & $12.0 \pm 1.0$ & \\
\hline & $3 / 17 / 97$ & 1225 & 14.1 & 8.0 & 495 & $10.7 \pm 0.7$ & \\
\hline & $3 / 09 / 98$ & 1310 & 14.2 & 7.9 & 478 & $10.5 \pm 0.7$ & \\
\hline & $3 / 16 / 99$ & 1710 & 13.7 & 8.0 & 504 & $10.6 \pm 0.7$ & \\
\hline Riley Creek & $3 / 07 / 94$ & 1405 & 15.5 & 8.1 & 333 & $11.0 \pm 0.7$ & \multirow{7}{*}{ Replicate } \\
\hline below Lewis Creek & $3 / 27 / 95$ & 1330 & 15.4 & 8.3 & 332 & $8.7 \pm 0.6$ & \\
\hline \multirow[t]{5}{*}{ nr Hagerman } & $3 / 11 / 96$ & 1300 & 15.7 & 8.2 & 331 & $8.8 \pm 0.8$ & \\
\hline & & & & & & $8.3 \pm 0.6$ & \\
\hline & $3 / 17 / 97$ & 0945 & 14.8 & 8.1 & 334 & $7.2 \pm 0.6$ & \\
\hline & $3 / 09 / 98$ & 0950 & 14.1 & 8.0 & 330 & $9.4 \pm 0.7$ & \\
\hline & $3 / 16 / 99$ & 1425 & 14.8 & 8.3 & 331 & $7.4 \pm 0.6$ & \\
\hline
\end{tabular}


Table 2. Physical and chemical characteristics of and tritium concentrations in water from selected springs in the Twin Falls-Hagerman area, Idaho, 1994-99-Continued

\begin{tabular}{|c|c|c|c|c|c|c|c|}
\hline Spring(s) name & $\begin{array}{c}\text { Date } \\
\text { sampled }\end{array}$ & Time & $\begin{array}{l}\text { Temper- } \\
\text { ature }\end{array}$ & $\mathrm{pH}$ & $\begin{array}{l}\text { Specific } \\
\text { conductance }\end{array}$ & $\begin{array}{c}\text { Tritium } \\
\text { concentration } \\
\text { and analytical } \\
\text { uncertainty }\end{array}$ & Remarks \\
\hline \multicolumn{8}{|c|}{ Category II Springs-continued } \\
\hline \multirow{7}{*}{$\begin{array}{l}\text { Sand Springs } \\
\text { nr Hagerman }\end{array}$} & $3 / 08 / 94$ & 1300 & 14.0 & 7.9 & 380 & $11.0 \pm 0.7$ & \multirow{7}{*}{ Replicate } \\
\hline & & & & & & $10.0 \pm 0.7$ & \\
\hline & $3 / 27 / 95$ & 1420 & 14.2 & 7.9 & 397 & $11.0 \pm 1.0$ & \\
\hline & $3 / 11 / 96$ & 1400 & 14.5 & 7.9 & 400 & $7.6 \pm 0.8$ & \\
\hline & $3 / 17 / 97$ & 1100 & 14.3 & 8.0 & 415 & $8.6 \pm 0.6$ & \\
\hline & 3/09/98 & 1100 & 14.2 & 7.9 & 405 & $7.3 \pm 0.6$ & \\
\hline & $3 / 16 / 99$ & 1535 & 13.9 & 7.9 & 397 & $6.6 \pm 0.6$ & \\
\hline \multirow{7}{*}{$\begin{array}{l}\text { Thousand Springs } \\
\text { nr Hagerman }\end{array}$} & $3 / 08 / 94$ & 0915 & 12.1 & 7.1 & 380 & $12.0 \pm 0.8$ & \multirow{7}{*}{ Replicate } \\
\hline & & & & & & $12.0 \pm 0.8$ & \\
\hline & $3 / 28 / 95$ & 1545 & 14.5 & 8.3 & 371 & $11.0 \pm 0.8$ & \\
\hline & $3 / 11 / 96$ & 1345 & 15.0 & 8.0 & 376 & $10.0 \pm 0.8$ & \\
\hline & $3 / 18 / 97$ & 0920 & 14.1 & 8.1 & 387 & $9.3 \pm 0.6$ & \\
\hline & $3 / 10 / 98$ & 1235 & 15.1 & 8.3 & 370 & $8.6 \pm 0.6$ & \\
\hline & $3 / 16 / 99$ & 1220 & 14.4 & 8.5 & 366 & $8.6 \pm 0.7$ & \\
\hline Spring btwn Blind & $3 / 09 / 94$ & 0950 & 12.4 & 8.7 & 446 & $11.0 \pm 0.8$ & \multirow{15}{*}{ Replicate } \\
\hline and Banbury & $3 / 28 / 95$ & 0955 & 12.0 & 8.6 & 433 & $9.5 \pm 0.7$ & \\
\hline \multirow[t]{5}{*}{ nr Buhl } & $3 / 11 / 96$ & 1100 & 14.0 & 8.2 & 436 & $9.7 \pm 1.0$ & \\
\hline & $3 / 18 / 97$ & 1035 & 13.6 & 8.5 & 450 & $10.0 \pm 0.6$ & \\
\hline & $3 / 10 / 98$ & 1020 & 13.0 & 8.4 & 435 & $8.6 \pm 0.6$ & \\
\hline & $3 / 16 / 99$ & 1045 & 12.9 & 8.5 & 431 & $8.0 \pm 0.6$ & \\
\hline & & & & & & $7.4 \pm 0.6$ & \\
\hline \multicolumn{7}{|c|}{ Category III Spring } & \\
\hline Birch Creek & $3 / 07 / 94$ & 0949 & 13.2 & 8.2 & 449 & $30.0 \pm 1.9$ & \\
\hline \multirow[t]{6}{*}{ nr Hagerman } & $3 / 27 / 95$ & 0955 & 13.3 & 8.4 & 442 & $26.0 \pm 1.5$ & \\
\hline & $3 / 11 / 96$ & 0930 & 14.3 & 8.4 & 446 & $24.0 \pm 1.4$ & \\
\hline & $3 / 17 / 97$ & 0810 & 13.2 & 7.9 & 447 & $21.9 \pm 1.5$ & \\
\hline & $3 / 09 / 98$ & 0835 & 12.8 & 8.3 & 435 & $22.3 \pm 1.5$ & \\
\hline & & & & & & $21.3 \pm 1.4$ & \\
\hline & $3 / 16 / 99$ & 1325 & 13.9 & 8.4 & 441 & $20.5 \pm 1.3$ & \\
\hline
\end{tabular}

Mann and Low (1994) indicated that the differences in tritium concentrations in Category I, II, and III springs are a function of the groundwater flow regimes, land uses, and irrigation practices in and hydraulically upgradient from each spring. In 1959, Mundorff and others (1964, p. 4) concluded that part of the ground water discharged to Category I springs originates in areas a few tens of miles east of Twin Falls, near Burley and Lake Walcott; their conclusion was based on a watertable map and a flow-net analysis of the Snake River Plain aquifer. The configuration of the water table in the spring of 1980, as described by Lindholm and others (1988), also supports this 
conclusion. In contrast, part of the ground water discharged to Category II springs originates in areas near Dubois and Rexburg, about $140 \mathrm{mi}$ northeast of Twin Falls, and part of the water discharged to the Category III spring originates in the Big and Little Wood River basins.

For the years 1994-99, tritium concentrations in flow from all 19 springs along the north side of the Snake River ranged from $6.5 \pm 0.6$ to $65.0 \pm 4.5 \mathrm{pCi} /$ $\mathrm{L}$ (table 2) and averaged $21.7 \mathrm{pCi} / \mathrm{L}$; the standard error of estimate for the mean concentration was $1.5 \mathrm{pCi} / \mathrm{L}$. Flow from Category I springs contained larger concentrations of tritium than flow from downstream springs. Tritium concentrations in flow from Category I springs ranged from $38.4 \pm 2.6$ to $65.0 \pm 4.5 \mathrm{pCi} / \mathrm{L}$ and averaged $48.5 \mathrm{pCi} / \mathrm{L}$ with a standard error of estimate for the mean concentration of $3.3 \mathrm{pCi} / \mathrm{L}$. In contrast, concentrations in flow from Category II springs ranged from $6.5 \pm 0.6$ to $13.0 \pm 1.0 \mathrm{pCi} / \mathrm{L}$ and averaged $9.4 \mathrm{pCi} / \mathrm{L}$; the standard error of estimate for the mean concentration was $0.71 \mathrm{pCi} / \mathrm{L}$. Flow from the Category III spring contained smaller concentrations of tritium than Category I springs, and larger concentrations than Category II springs. Tritium concentrations in water samples from the Category III spring ranged from $20.5 \pm 1.3$ to $30.0 \pm 1.9 \mathrm{pCi} / \mathrm{L}$, respectively; the average concentration was $23.7 \mathrm{pCi} / \mathrm{L}$ and the standard error for the mean was $1.5 \mathrm{pCi} / \mathrm{L}$.

Decreasing tritium concentrations in springs sampled in the Twin Falls-Hagerman area were first described by Mann and Low (1994). Figure 3 shows tritium concentrations in three selected springs (Blue Lakes, Banbury Spring, and Birch Creek Spring) for the years 1990-99. During that period, mean annual tritium concentrations decreased about 5 percent per year. Tritium data for 1990-93 sample period can be found in Mann and Low (1994, p. 8). During 1990-99 sample period, tritium concentrations for the Category I spring (Blue Lakes) decreased from a high of $65.3 \pm 4.5$ in 1990 to a low of $38.4 \pm 2.6 \mathrm{pCi} / \mathrm{L}$ in 1999 (table 2); concentrations in the Category II spring (Banbury) decreased from a high of $14.7 \pm 1.0$ in 1990 to a low of $7.1 \pm 0.6 \mathrm{pCi} / \mathrm{L}$ in 1999 (table 2); concentrations in the Category III spring (Birch Creek) decreased from a high of $47.7 \pm 3.2$ in 1990 to a low of $20.5 \pm 1.3 \mathrm{pCi} / \mathrm{L}$ in 1999 (table 2). The decreasing tritium values are likely the result of natural isotope decay resulting from the short half-life of tritium of 12.3 years (Walker and others, 1989).

\section{SUMMARY}

Concern has been expressed that some of the $31,000 \mathrm{Ci}$ of tritium in wastewater discharged to the Snake River Plain aquifer at the INEEL since the 1950's could migrate to the Snake River in the Twin Falls-Hagerman area. Water downgradient from the INEEL is used for drinking, irrigation, and aquaculture. Nineteen springs along the north side of the Snake River were sampled annually during 1994-99, as part of a long-term project to monitor water quality of springs discharging from the Snake River Plain aquifer downgradient from the INEEL. During 1994-99, tritium concentrations ranged from $6.5 \pm 0.6$ to $65.0 \pm 4.5 \mathrm{pCi} / \mathrm{L}$. On the basis of their locations and tritium concentrations, the springs were placed into three categories: Category I springs are the farthest upstream and contained from $38.4 \pm 2.6$ to $65.0 \pm 4.5 \mathrm{pCi} / \mathrm{L}$ of tritium; Category II springs are downstream from those in Category I and contained from $6.5 \pm 0.6$ to $13.0 \pm 1.0 \mathrm{pCi} / \mathrm{L}$; and Category III springs are the farthest downstream and contained from $20.5 \pm 1.3$ to $30.0 \pm 1.9 \mathrm{pCi} / \mathrm{L}$. Tritium concentrations demonstrate decreasing trends for the sample period 1990-99, likely the result of natural isotope decay.

\section{REFERENCES CITED}

Bartholomay, R.C., Tucker, B.J., Ackerman, D.J., and Liszewski, M.J., 1997, Hydrologic conditions and distribution of selected radiochemical and chemical constituents in water, Snake River Plain aquifer, Idaho National Engineering Laboratory, Idaho, 1992 through 1995: U.S. Geological Survey Water-Resources Investigations Report 97-4086 (DOE/ID-22137), $57 \mathrm{p}$.

Bartholomay, R.C., Tucker, B.J., Davis, L.C., and Greene, M.R., 2000, Hydrologic conditions and distribution of selected constituents in water, Snake River Plain aquifer, Idaho National Engineering and Environmental Laboratory, Idaho, 1996 through 1998: U.S. Geological Survey Water-Resources Investigations Report 00-4192 (DOE/ID-22167), $52 \mathrm{p}$.

Cecil, D.L., Knobel, L.L., Green, J.R., Frape, S.K., 2000 , In situ production of chlorine-36 in the East- 


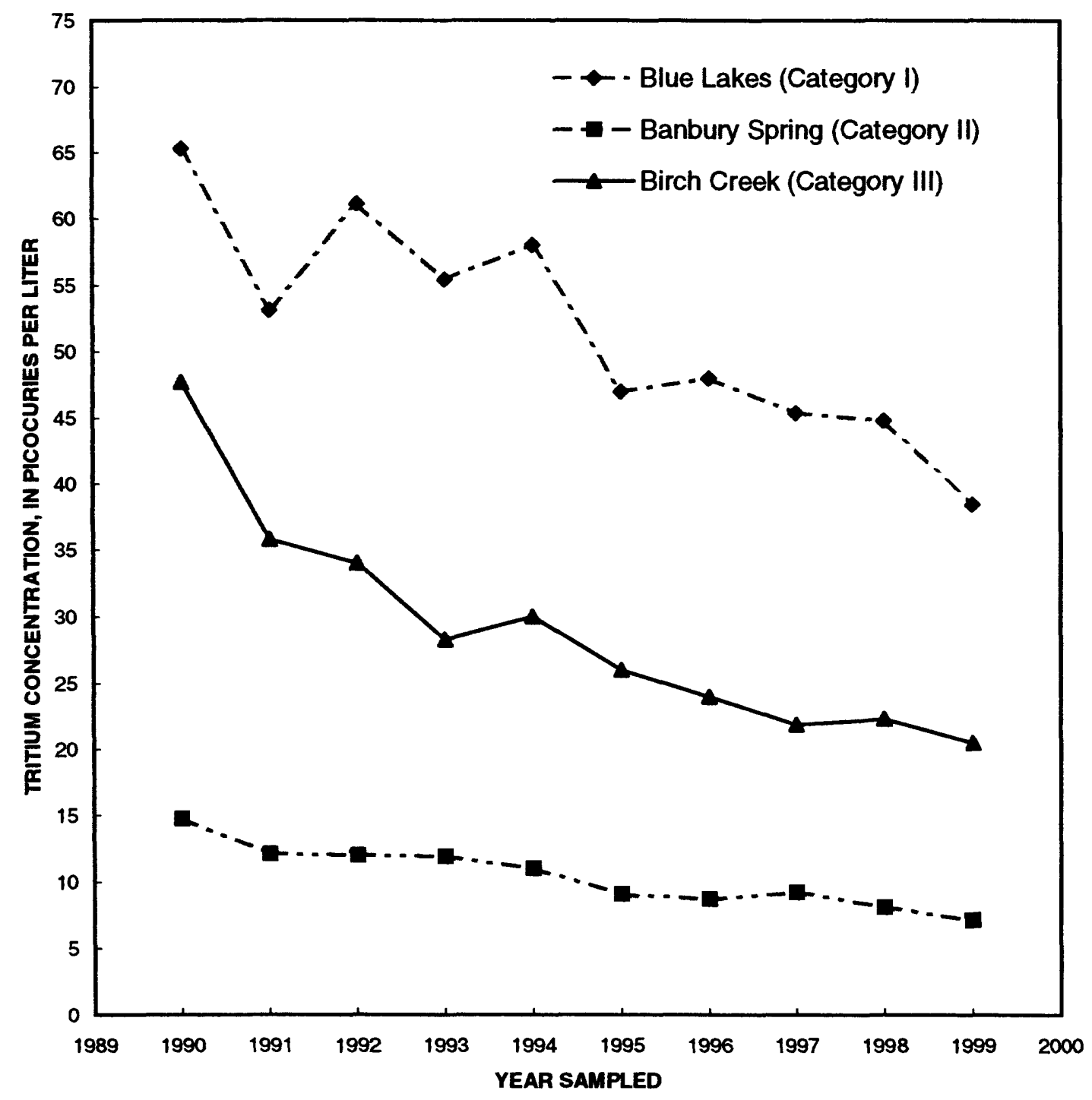

Figure 3. Concentrations of tritium in selected Category I, II, and III springs, 1990-99 (1990-93 data were taken from Mann and Low, 1994, p. 8). 
ern Snake River Plain Aquifer, Idaho-implications for describing ground-water contamination near a nuclear facility: U.S. Geological Survey Water-Resources Investigations Report 00-4114 (DOE/ID-22166), $35 \mathrm{p}$.

Friedman, L.C., and Erdmann, D.E., 1982, Quality assurance practices for the chemical and biological analyses of water and fluvial sediments: U.S. Geological Survey Techniques of Water-Resources Investigations, book 5, chap A6, $181 \mathrm{p}$.

Jones, B.E., 1987, Quality control manual of the U.S. Geological Survey's National Water Quality Laboratory: U.S. Geological Survey Open-File Report $87-457,17 \mathrm{p}$.

Lindholm, G.F., Garabedian, S.P., Newton, G.D., and Whitehead, R.L., 1988, Configuration of the water table and depth to water, spring 1980 , water-level fluctuations, and water movement in the Snake River Plain regional aquifer system, Idaho and eastern Oregon: U.S. Geological Survey Hydrologic Investigations Atlas HA-703, 1 sheet, scale $1: 500,000$.

Mann, L.J., 1996, Quality-assurance plan and field methods for quality-of-water activities, U.S. Geological Survey, Idaho National Engineering Laboratory, Idaho: U.S. Geological Survey Open-File Report 96-615 (DOE/ID-22132), 37 p.

Mann, L.J., Low, W.H., 1994, Tritium, stable isotopes, and nitrogen in flow from selected springs that discharge to the Snake River, Twin Falls-Hagerman area, Idaho, 1990-93: U.S. Geological Survey Water-Resources Investigations Report 94-4247 (DOE/ID-22119), $21 \mathrm{p}$.

Michel, R.L., 1989, Tritium deposition in the continental United States, 1953-83: U.S. Geological Survey Water-Resources Investigations Report 89-4072, $46 \mathrm{p}$.

Mundorff, M.J., Crosthwaite, E.G., and Kilburn, Chabot, 1964, Ground water for irrigation in the Snake River Basin in Idaho: U.S. Geological Survey Water-Supply Paper 1654, 224 p.
National Council on Radiation Protection and Measurements, 1979, Tritium in the environment: National Council on Radiation Protection and Measurements Report No. 62, 125 p.

Pittman, J.R., Jensen, R.J., and Fischer, P.R., 1988, Hydrologic conditions at the Idaho National Engineering Laboratory, 1982 to 1985 : U.S. Geological Survey Water-Resources Investigations Report 894008, 73 p.

Pritt, J.W., and Jones, B.E., eds., 1989, 1990 National Water Quality Laboratory services catalog: U.S. Geological Survey Open-File Report 89-386 [variously paged].

Pritt, J.W., and Raese, J.W., eds., 1995, Quality assurance/quality control manual-National Water Quality Laboratory: U.S. Geological Survey OpenFile Report 95-443, 35 p.

Thatcher, L.L., Janzer, V.J., and Edwards, K.W., 1977, Methods for determination of radioactive substances in water and fluvial sediments: U.S. Geological Survey Techniques of Water-Resources Investigations, book 5, chap. A5, $95 \mathrm{p}$.

U.S. Environmental Protection Agency, 1983, Protection of environment, Subpart B of Part 141: U.S. Code of Federal Regulations, Title 40, Parts 100149 , revised as of July $1,1983,399 \mathrm{p}$.

Walker, F.W., Parrington, J.R., and Feiner, Frank, 1989, Nuclides and isotopes, chart of the nuclides (14th ed.): General Electric Company, Nuclear Energy Operations, $57 \mathrm{p}$.

Wilde, F.D., Radtke, D.B., Gibs, J., and Iwatsubo, R.T., 1998, National field manual for the collection of water-quality data: U.S. Geological Survey Techniques of Water-Resources Investigations, book 9 [variously paged].

Wood, W.W., 1976, Guidelines for collection and field analysis of ground-water samples for selected unstable constituents: U.S. Geological Survey Techniques of Water-Resources Investigations, book 1, chap. D2, 24 p. 